\title{
A PRELIMINARY MOLECULAR ANALYSIS OF PHYLOGENETIC RELATIONSHIPS OF AUSTRALASIAN WOLF SPIDER GENERA (ARANEAE, LYCOSIDAE)
}

\author{
Cor J. Vink, Anthony D. Mitchell and Adrian M. Paterson: Ecology \& \\ Entomology Group, P.O. Box 84, Lincoln University, Canterbury 8150, New Zealand
}

\begin{abstract}
A data-set from the mitochondrial 12S rRNA gene subunit of 11 Australasian lycosid species (six New Zealand species and five Australian species) was generated. Three North American lycosid species, one European species and one New Zealand pisaurid (outgroup) were also sequenced. The sequence data for the 16 species were combined with the published sequences of 12 European lycosids, two Asian lycosids and one Asian pisaurid and were analyzed using parsimony and maximum likelihood analyses. The resulting phylogenetic trees reveal that Australasian species largely form clades distinct from Palearctic and Holarctic species providing further evidence against the placement of Australasian species in Northern Hemisphere genera. New Zealand wolf spiders appear to be related to a subset of Australian genera whereas the other Australian lycosid genera are related to Asian/Holarctic faunas. Gene sequences in the $12 \mathrm{~S}$ region were useful when examining relationships between closely related genera, but were not as informative for deeper generic relationships.
\end{abstract}

Keywords: Lycosidae, New Zealand, Australia, lycosid genera, lycosid subfamilies

The monophyly of the Lycosidae is well supported (e.g. Dondale 1986; Griswold 1993), but at the subfamily level there is some disagreement (Dondale 1986; Zyuzin 1993; Dippenaar-Schoeman \& Jocqué 1997) and lycosid genera, many of which are paraphyletic and polyphyletic, are in disarray. Although European lycosid generic placements are well established (e.g. Heimer \& Nentwig 1991) and some Nearctic and African genera have been recently revised (e.g. Alderweireldt 1991, 1999; Dondale \& Redner 1978, 1979, 1983a, 1983b; Russell-Smith 1982), a large number of the 2245 lycosid species (Platnick 2001) would seem to be misplaced. For example, a revision of the New Zealand lycosid fauna (Vink 2002) found that all but one described species were incorrectly placed in mostly Northern Hemisphere genera. Some of the confusion can be attributed to Roewer (1951, 1955, 1959, 1960) who described 65 lycosid genera of which only 31 are currently recognized (Platnick 2001); 12 of these are monotypic and many others contain only two species. Roewer's generic descriptions were short and based on highly variable, non-genitalic characters. Brignoli (1983) stated "it is apparent that most recent students of this group give little value to most of the genera described by Roewer in 1954 [1955] and 1960; still it is necessary to list them as no acceptable new 'system' has been yet proposed". However, Roewer cannot be held entirely responsible for the state of lycosid genera. Many of the generic problems are due to the morphological conservatism of the Lycosidae and the consequential lack of useful characters to define and separate genera.

In New Zealand and Australia, many early workers placed lycosid species into genera with which they were familiar in their native Europe (e.g. Koch 1877). In particular, Lycosa Latreille 1804, which is now considered to be a Mediterranean genus (Zyuzin \& Logunov 2000), has been a convenient genus in which to place many new species or as a temporary home when genera need revising (e.g. McKay 1975). Many of the large, burrow-dwelling Australian species have been placed in Lycosa (e.g. Lycosa godeffroyi L. Koch 1865) but do not fit the genus as defined by Zyuzin \& Logunov (2000). Rather, they have a genitalic morphology similar to Geolycosa Montgomery 1904 (sensu Dondale \& Redner 1990).

Lycosids are among the numerically dominant arthropod predators found in open habi- 
tats in Australasia (e.g. Forster 1975; Humphreys 1976; Churchill 1993; Sivasubramaniam et al. 1997; Hodge \& Vink 2000; Framenau et al. 2002) and recent taxonomic work (Framenau 2002; Framenau \& Vink 2001; Vink 2001, 2002) has addressed the generic placement of some Australasian species. New Zealand's fauna, comprising 27 species, has been revised (Vink 2002) with most species (20) in Anoteropsis L. Koch 1878. The Australasian genera Allotrochosina Roewer 1960 (two species), Artoria Thorell 1877 (17 species), Notocosa Vink 2002 (one species) and Venatrix Roewer 1960 (22 species) have been recently revised or reviewed (Framenau 2002; Framenau \& Vink 2001; Vink 2001, 2002). There are also 12 Australian species that form "a natural grouping" and were placed in Trochosa C.L. Koch 1848 (McKay 1979) but none of these species fit the genus as defined by Dondale \& Redner (1990). Australia has 141 described lycosid species and at least another 100 undescribed species (V.W. Framenau pers. comm.; CJV pers. obs.). The majority of Australian species appear to belong in $\mathrm{Ar}$ toria and a Geolycosa-like genus (V.W. Framenau pers. comm.; CJV pers. obs.). Species in Venatrix and the Geolycosa-like genus have a pedipalpal configuration that places them in the Lycosinae Simon 1898 (Framenau \& Vink 2001; CJV pers. obs.). Vink (2001) placed $A l$ lotrochosina in Venoniinae Lehtinen \& Hippa 1979 (sensu Dondale 1986) and while the simple pedipalps of Anoteropsis, Artoria, Notocosa and the Australian species currently in Trochosa do not fit any of the current subfamily definitions (Framenau 2002; Vink 2002; CJV pers. obs.) they are perhaps closest to Venoniinae (sensu Dondale 1986). The phylogenetic position of Australasian genera within the Lycosidae is unknown.

Because lycosids are morphologically conservative it is unlikely that sufficient numbers of morphological characters could be found to infer phylogenetic relationships of Australasian genera to their counterparts in the rest of the world. Sequence data from a portion of the mitochondrial 12S rRNA gene of the small ribosomal subunit have yielded large data sets for phylogenetic analysis of spiders (e.g. Gillespie et al. 1994). Recently, 12S rRNA sequence data have been used to infer relationships among European lycosids (Zehethofer \& Sturmbauer 1998; Vink \& Mitchell 2002) and the relationship of Asian lycosids to other Lycosoidea (Fang et al. 2000). Zehethofer \& Sturmbauer (1998) found that 12S rRNA was especially suitable for resolving relationships higher than the species level.

This preliminary study aimed to examine the relationship of exemplars of the major Australasian genera to exemplars of genera found elsewhere in the world using phylogenetic analyses of $12 \mathrm{~S}$ rDNA sequence data.

\section{METHODS}

Generic placement of species was based on the latest catalog of Platnick (2001) and recent taxonomic revisions (Framenau 2002; Framenau \& Vink 2001; Vink 2001, 2002). Species sequenced, sex, and collection details (locality, date and collectors) are shown in Table 1. All specimens are stored in $95 \%$ ethanol and refrigerated in the Ecology \& Entomology Group, Lincoln University. Selected Australasian species represented the major species groups of Australia and New Zealand (Framenau 2002; Framenau \& Vink 2001; Vink 2001, 2002; CJV pers. obs.). The North American species Geolycosa rogersi Wallace 1942, Varacosa avara (Keyserling 1877) and Allocosa georgicola (Walckenaer 1837) were sequenced and included in the analysis because of the similarity of their male pedipalp morphology to Lycosa godeffroyi. It should be noted that Allocosa georgicola does not fit the genus Allocosa Banks 1900 as defined by Dondale \& Redner (1983b).

DNA extraction, amplification and sequencing.- Specimens were washed in sterile deionized, distilled water before DNA extraction. Total genomic DNA was extracted by homogenizing 1-2 legs from single individuals (Table 1) using a proteinase- $\mathrm{K}$ digestion and high salt precipitation method (White et al. 1990). Mitochondrial $12 \mathrm{~S}$ regions were amplified using the following two primer combinations:

1) 12St-L (5'-GGTGGCATTTTATTTTATTAGAGG-3') (Croom et al. 1991) plus 12Sbi-H (5'-AAGAGCGACGGGCGATGTGT-3') (Simon et al. 1990), or

2) $12 \mathrm{SR}-\mathrm{N}-14594$ (5'-AAACTAGGATTAGATACCC-3') plus 12SR-J-14199 (5' TACTATGTTACGACTTAT-3') (Kambhampati \& Smith 1995) (Fig. 1).

Each $25 \mu$ l reaction consisted of $1 \times T a q$ 
Table 1.- Specimens sequenced showing species, sex, collection localities, collectors and dates collected, primers used and GenBank accession numbers.

\begin{tabular}{|c|c|c|c|c|}
\hline Species & Sex & Collection details & Primers used & $\begin{array}{c}\text { GeneBank } \\
\text { accession } \\
\text { no. }\end{array}$ \\
\hline $\begin{array}{l}\text { Allocosa georgicola } \\
\text { (Walckenaer 1837) }\end{array}$ & female & $\begin{array}{l}\text { USA, near Oxford }\left(34^{\circ} 13^{\prime} \mathrm{N},\right. \\
\left.89^{\circ} 19^{\prime} \mathrm{W}\right), 12 . x .1999, \mathrm{~L} . \\
\text { Schaffer }\end{array}$ & $12 \mathrm{SR}-\mathrm{J}+12 \mathrm{SR}-\mathrm{N}$ & AF380499 \\
\hline $\begin{array}{l}\text { Alopecosa barbipes } \\
\text { (Sundevall 1833) }\end{array}$ & male & $\begin{array}{l}\text { England, Redgrave \& Lopham } \\
\text { Fen }\left(52^{\circ} 23^{\prime} \text { N, } 01^{\circ} 00^{\prime} \mathrm{E}\right) \\
\text { 6.x.1999, C.J. Vink \& M.A. } \\
\text { Hudson }\end{array}$ & $12 \mathrm{St}-\mathrm{L}+12 \mathrm{Sbi}$ & AY028420 \\
\hline $\begin{array}{l}\text { Allotrochosina schauins- } \\
\quad \text { landi (Simon 1899) }\end{array}$ & female & $\begin{array}{l}\text { New Zealand, Prices Valley } \\
\left(43^{\circ} 48^{\prime} \mathrm{S}, 172^{\circ} 41^{\prime} \mathrm{E}\right) \text {, } \\
\text { 12.vi.1999, C.J. Vink \& J.W. } \\
\text { Griffiths }\end{array}$ & $12 \mathrm{St}-\mathrm{L}+12 \mathrm{Sbi}$ & AF380502 \\
\hline $\begin{array}{l}\text { Anoteropsis adumbrata } \\
\text { (Urquhart 1887) }\end{array}$ & female & $\begin{array}{l}\text { New Zealand, Titan Rocks } \\
\left(45^{\circ} 32^{\prime} \mathrm{S}, 169^{\circ} 00^{\prime} \mathrm{E}\right), \\
\text { 9.xii. } 1998, \mathrm{G} \text {. Hall, B. Brown } \\
\text { \& E. Edwards }\end{array}$ & $12 \mathrm{St}-\mathrm{L}+12 \mathrm{Sbi}$ & AF380491 \\
\hline $\begin{array}{l}\text { Anoteropsis lacustris } \\
\quad \text { Vink } 2002\end{array}$ & male & $\begin{array}{l}\text { New Zealand, Arthur's Pass } \\
\left(42^{\circ} 56^{\prime} \mathrm{S}, 171^{\circ} 34^{\prime} \mathrm{E}\right) \\
\text { 9.iv.1999, C.J. Vink \& M.A. } \\
\text { Hudson }\end{array}$ & $12 \mathrm{St}-\mathrm{L}+12 \mathrm{Sbi}$ & AF380489 \\
\hline $\begin{array}{l}\text { Anoteropsis senica } \\
\text { (L. Koch 1887) }\end{array}$ & male & $\begin{array}{l}\text { New Zealand, Franz Josef Gla- } \\
\text { cier }\left(43^{\circ} 25^{\prime} \mathrm{S}, 170^{\circ} 10^{\prime} \mathrm{E}\right) \\
\text { iv. } 1999, \text { C.J. Vink \& M.A. } \\
\text { Hudson }\end{array}$ & $12 \mathrm{SR}-\mathrm{J}+12 \mathrm{SR}-\mathrm{N}$ & AF380490 \\
\hline $\begin{array}{l}\text { Artoria flavimanus } \\
\quad \text { Simon } 1909\end{array}$ & male & $\begin{array}{l}\text { Australia, Crowea }\left(34^{\circ} 28^{\prime} \mathrm{S},\right. \\
\left.116^{\circ} 10^{\prime} \mathrm{E}\right), 6 . \mathrm{v} .1999, \text { C.J. } \\
\text { Vink }\end{array}$ & $12 \mathrm{SR}-\mathrm{J}+12 \mathrm{SR}-\mathrm{N}$ & AF380492 \\
\hline $\begin{array}{l}\text { Dolomedes minor } \\
\text { L. Koch } 1876\end{array}$ & female & $\begin{array}{l}\text { New Zealand, Lake Ellesmere } \\
\left(43^{\circ} 43^{\prime} \mathrm{S}, 172^{\circ} 30^{\prime} \mathrm{E}\right), \\
\text { 20.xi.1999, R.M. Emberson }\end{array}$ & $12 \mathrm{SR}-\mathrm{J}+12 \mathrm{SR}-\mathrm{N}$ & AF380503 \\
\hline $\begin{array}{l}\text { Geolycosa rogersi } \\
\text { Wallace } 1942\end{array}$ & female & $\begin{array}{l}\text { USA, Avent Park } 34^{\circ} 13^{\prime} \mathrm{N}, \\
\left.89^{\circ} 18^{\prime} \mathrm{W}\right) \text {, 1.iv. } 2000 \text {, G. Strat- } \\
\text { ton, P. Miller \& B. Suter }\end{array}$ & $12 \mathrm{SR}-\mathrm{J}+12 \mathrm{SR}-\mathrm{N}$ & AF380498 \\
\hline $\begin{array}{l}\text { Lycosa godeffroyi } \\
\text { L. Koch } 1865\end{array}$ & female & $\begin{array}{l}\text { Australia, Bellerive }\left(42^{\circ} 52^{\prime} \mathrm{S} \text {, }\right. \\
\left.147^{\circ} 22^{\prime} \mathrm{E}\right), 11 . \mathrm{v} .1999, \text { C.J. } \\
\text { Vink \& J. Cossum }\end{array}$ & $12 \mathrm{SR}-\mathrm{J}+12 \mathrm{SR}-\mathrm{N}$ & AF380497 \\
\hline $\begin{array}{l}\text { Notocosa bellicosa } \\
\text { (Goyen 1887) }\end{array}$ & male & $\begin{array}{c}\text { New Zealand, Temuka }\left(44^{\circ} 14^{\prime} \mathrm{S},\right. \\
\left.171^{\circ} 17^{\prime} \mathrm{E}\right), \text { iii. } 1999, \text { M. Ross }\end{array}$ & $12 \mathrm{SR}-\mathrm{J}+12 \mathrm{SR}-\mathrm{N}$ & AF380493 \\
\hline $\begin{array}{l}\text { Trochosa oraria } \\
\text { (L. Koch 1876) }\end{array}$ & female & $\begin{array}{l}\text { Australia, Lauderdale }\left(42^{\circ} 55^{\prime} \mathrm{S},\right. \\
\left.147^{\circ} 29^{\prime} \mathrm{E}\right), 11 . \text { v. } 1999, \text { C.J. } \\
\text { Vink \& J. Cossum }\end{array}$ & $12 \mathrm{St}-\mathrm{L}+12 \mathrm{Sbi}$ & AF380501 \\
\hline $\begin{array}{l}\text { Varacosa avara } \\
\quad \text { (Keyserling 1877) }\end{array}$ & male & $\begin{array}{l}\text { USA, Sardis Reservoir } \\
\left(34^{\circ} 15^{\prime} \mathrm{N}, 89^{\circ} 28^{\prime} \mathrm{W}\right) \\
14 . i x .1999, \mathrm{G} . \text { Stratton \& W. } \\
\text { Calvert }\end{array}$ & $12 \mathrm{SR}-\mathrm{J}+12 \mathrm{SR}-\mathrm{N}$ & AF380500 \\
\hline $\begin{array}{l}\text { Venatrix goyderi } \\
\quad \text { (Hickman 1944) }\end{array}$ & female & $\begin{array}{l}\text { New Zealand, near Matarau } \\
\left(35^{\circ} 38^{\prime} \mathrm{S}, 174^{\circ} 11^{\prime} \mathrm{E}\right), \\
\text { 15.ii.1999, C.J. Vink }\end{array}$ & $12 \mathrm{St}-\mathrm{L}+12 \mathrm{Sbi}$ & AF380496 \\
\hline $\begin{array}{l}\text { Venatrix lapidosa } \\
\text { (McKay 1974) }\end{array}$ & male & $\begin{array}{l}\text { Australia, Avon River }\left(37^{\circ} 48^{\prime} \mathrm{S} \text {, }\right. \\
\left.146^{\circ} 57^{\prime} \mathrm{E}\right) \text {, iii. } 1999, \text { V.W. Fra- } \\
\text { menau }\end{array}$ & $12 \mathrm{SR}-\mathrm{J}+12 \mathrm{SR}-\mathrm{N}$ & AF380495 \\
\hline $\begin{array}{l}\text { Venatrix pictiventris } \\
\text { (L. Koch 1877) }\end{array}$ & male & $\begin{array}{l}\text { Australia, Queens Domain } \\
\left(42^{\circ} 52^{\prime} \mathrm{S}, 147^{\circ} 19^{\prime} \mathrm{E}\right) \text {, 9.v.1999, } \\
\text { C.J. Vink }\end{array}$ & $12 \mathrm{St}-\mathrm{L}+12 \mathrm{Sbi}$ & AF380494 \\
\hline
\end{tabular}




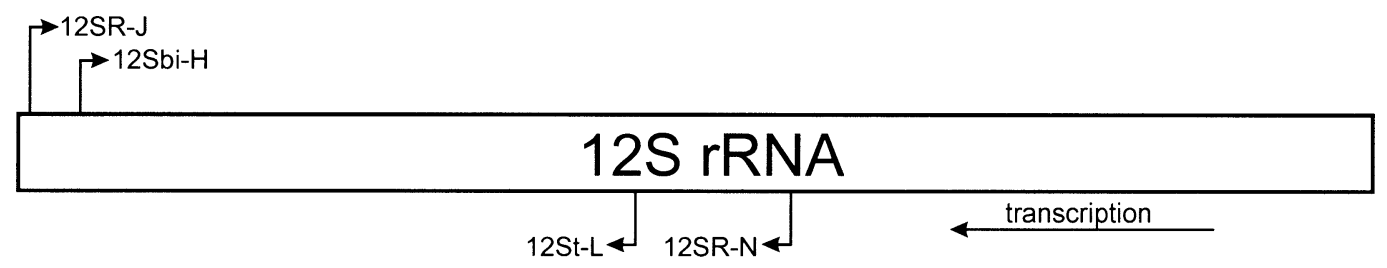

Figure 1.-Gene region coding for $12 \mathrm{~S}$ rRNA showing areas sequenced by primers and direction of transcription.

buffer, $0.25 \mathrm{mM}$ dNTPs, $2 \mathrm{mM} \mathrm{MgCl}_{2}, 0.4$ $\mu \mathrm{M}$ of each primer, 1.25 units Taq DNA Polymerase (Roche) and $1 \mu \mathrm{l}$ of genomic DNA [which was diluted 1:20 in TE (10 mM Tris, $1 \mathrm{mM}$ EDTA, pH 8.0) and used as a template for the amplification of double-stranded DNA (dsDNA)]. Amplification was performed in a GeneAmp ${ }^{\circledR}$ PCR System 2400 (Perkin-Elmer) thermocycler and the following temperature profile was used: $4 \mathrm{~min}$. at $94{ }^{\circ} \mathrm{C} ; 40$ cycles of $20 \mathrm{~s}$ at $94{ }^{\circ} \mathrm{C}, 30 \mathrm{~s}$ at $50{ }^{\circ} \mathrm{C}, 40 \mathrm{~s}$ at $72{ }^{\circ} \mathrm{C}$; $2 \mathrm{~min}$. at $72{ }^{\circ} \mathrm{C}$. Excess primers and salts were removed from the resulting dsDNA by precipitation with $100 \%$ isopropanol in the presence of $2.5 \mathrm{M} \mathrm{NH}_{4} \mathrm{Ac}$, followed by a $70 \%$ ethanol wash. Purified PCR fragments were sequenced using ABI PRISM ${ }^{\circledR}$ BigDye $^{\circledR i}$ termination mix version 1 (Perkin-Elmer) and separated on an ABI PRISM ${ }^{\circledR} 373$ automatic sequencer. The sense and antisense strands were sequenced for all species except Venatrix pictiventris L. Koch 1877 and Anoteropsis la- custris Vink 2002, which were successful only one way. Sequence data were deposited in GenBank (Benson et al. 2000) (see Table 1 for accession numbers).

Data analysis.- Sequences were aligned to 15 previously published sequences (Zehethofer \& Sturmbauer 1998; Fang et al. 2000) (Table 2) using Clustal W 1.7 (Thompson et al. 1994), then confirmed by eye. Insertion/deletion events were inferred where necessary based on the secondary structure of $12 \mathrm{~S} \mathrm{rRNA}$ proposed by Hickson et al. (1996). Although Hickson et al. (1996) used the 12S sequence of Tetragnatha mandibulata Walckenaer 1842 when constructing their template, helix 42 did not seem to be present in the lycosid or pisaurid sequences. In order to match the data obtained by Zehethofer \& Sturmbauer (1998) sequence data that began five bases downstream from where the $12 \mathrm{St}-\mathrm{L}$ primer annealed to seven bases upstream from where the $12 \mathrm{Sbi}-\mathrm{H}$ primer annealed were included in

Table 2.- Other published sequences used in analyses showing species, reference and Genebank accession numbers.

\begin{tabular}{|c|c|c|}
\hline Species & Reference & $\begin{array}{c}\text { GenBank } \\
\text { accession } \\
\text { no. }\end{array}$ \\
\hline Alopecosa accentuata (Latreille 1817) & Zehethofer \& Sturmbauer (1998) & AJ008022 \\
\hline Alopecosa pulverulenta (Clerck 1757) & Zehethofer \& Sturmbauer (1998) & AJ008025 \\
\hline Arctosa leopardus (Sundevall 1833) & Zehethofer \& Sturmbauer (1998) & AJ008032 \\
\hline Dolomedes raptor Bösenberg \& Strand 1906 & Fang et al. (2000) & AF145031 \\
\hline Lycosa coelestis L. Koch 1878 & Fang et al. (2000) & AF145030 \\
\hline Pardosa agrestis (Westring 1861) & Zehethofer \& Sturmbauer (1998) & AJ008033 \\
\hline Pardosa hortensis (Thorell 1872) & Zehethofer \& Sturmbauer (1998) & AJ008007 \\
\hline Pardosa palustris (Linnaeus 1758) & Zehethofer \& Sturmbauer (1998) & AJ008011 \\
\hline Pardosa takahashii (Saito 1936) & Fang et al. (200) & AF145032 \\
\hline Pirata hygrophilus Thorell 1872 & Zehethofer \& Sturmbauer (1998) & AJ008015 \\
\hline Pirata knorri (Scopoli 1763) & Zehethofer \& Sturmbauer (1998) & AJ008019 \\
\hline Trochosa terricola Thorell 1856 & Zehethofer \& Sturmbauer (1998) & AJ008017 \\
\hline Trochosa spinipalpis (F.O.P.-Cambridge 1895) & Zehethofer \& Sturmbauer (1998) & AJ008016 \\
\hline Xerolycosa miniata (C.L. Koch 1834) & Zehethofer \& Sturmbauer (1998) & AJ008021 \\
\hline Xerolycosa nemoralis (Westring 1861) & Zehethofer \& Sturmbauer (1998) & AJ008020 \\
\hline
\end{tabular}


the analyses. The analyses were conducted using PAUP* 4.0b4a (Swofford 2000).

Data were analyzed as unordered characters, first using parsimony and the heuristic search (1000 replicates) option in PAUP*. All characters were equally weighted, and zero length branches were collapsed to polytomies. Bootstrap values (Felsenstein 1985) were calculated from 1000 replicate parsimony analyses using the heuristic search option in PAUP*. Modeltest version 3.06 (Posada \& Crandall 1998) was used to select the maximum likelihood parameters, GTR $+\Gamma+\mathrm{I}$. The general time reversible model (Yang 1994) was used to estimate the maximum likelihood tree and branches were collapsed (creating polytomies) if the branch length was less than or equal to $1 \mathrm{e}-08$. The maximum likelihood analysis included 20 taxa. Taxa were pruned if they were part of a well-supported node (bootstrap value $>75 \%$ ) in the parsimony tree leaving one representative of each taxon. Bootstrap values were calculated from 100 replicate likelihood analyses using the heuristic search option in PAUP*.

\section{RESULTS}

The primer combination $12 \mathrm{St}-\mathrm{L}$ plus 12Sbi-H produced a single amplification product for seven species (see Table 1), but two or more bands were amplified for all other taxa. The primer pair 12SR-J-14199 plus 12SR-N-14594 was used to amplify product for sequencing for the taxa that did not produce a single amplification product using the $12 \mathrm{St}-\mathrm{L}$ plus $12 \mathrm{Sbi}-\mathrm{H}$ combination (see Table $1)$. The $12 \mathrm{St}-\mathrm{L}$ primer site varied considerably in the nine taxa for which the primer pair 12SR-J-14199 plus 12SR-N-14594 was used, which may explain why the primer combination $12 \mathrm{St}-\mathrm{L}$ plus $12 \mathrm{Sbi}-\mathrm{H}$ did not work for all taxa. The primer $12 \mathrm{St}-\mathrm{L}$ was designed as a Tetragnatha-specific primer (Croom et al. 1991) so it is not surprising that this site varies in lycosids. There was little variation evident in the $12 \mathrm{Sbi}-\mathrm{H}$ site even though this primer was designed as specific to insects (Simon et al. 1990). The nucleotide composition was A + T-rich $(44.2 \%$ A, $10.0 \%$ C, $9.8 \%$ G, $36.0 \%$ $\mathrm{T}$ ), which is typical for arthropods (Simon et al. 1994).

Parsimony analysis yielded 2 equally parsimonious trees (Fig. 2), 482 steps long, with a consistency index, excluding uninformative characters, of 0.415 and retention index of 0.577 . Of the 330 characters included in the analysis, 172 were variable with 113 of them parsimony informative. Maximum likelihood analysis resulted in six trees with scores of 2092.1969 (Fig. 3). The six trees had the same topology because the branches were collapsed (creating polytomies) if the branch length was less than or equal to $1 \mathrm{e}-08$. The topology of the maximum likelihood trees (Fig. 3) and the parsimony trees (Fig. 2) differed mainly in the lower branches, which had less than 50\% bootstrap support.

\section{DISCUSSION}

Molecular analysis confirms that most of the New Zealand or Australian lycosids included in the analysis do not belong in the Northern Hemisphere genera where they have been or are currently placed. This study confirms that Trochosa oraria L. Koch 1876 does not belong in the genus Trochosa (sensu Dondale \& Redner 1990) and the two Holarctic exemplars of Trochosa are monophyletic, which is supported by high bootstrap values (Fig. 2). There is support for the monophyly of Pardosa C.L. Koch 1847 as the four exemplars form a monophyletic clade that is supported by a high bootstrap value (Fig. 3). Zehethofer \& Sturmbauer (1998) also had strong support for the monophyly of the 14 exemplars of Pardosa that they included in their analysis. The three exemplars of Alopecosa Simon 1885 included in this study form a strongly supported monophyletic clade, as did the six exemplars included in the analysis of Zehethofer \& Sturmbauer (1998). The exemplars of Xerolycosa Dahl 1908 and Pirata Sundevall 1833 both have good support for their monophyly. The molecular evidence suggests that Allocosa georgicola belongs in a Geolycosa-like genus, however, there is poor bootstrap support and no Allocosa species (sensu Dondale \& Redner 1983b) were included in this analysis. Lycosa coelestis L. Koch 1878 does not fit the genus Lycosa as defined by Zyuzin \& Logunov (2000) and comes out as sister to Varacosa avara in both analyses with reasonable bootstrap support. However, Dondale \& Redner (1990) stated that Varacosa Chamberlin \& Ivie 1942 is restricted to North America. Both trees (Figs. 2, 3) support the monophyly of the clade containing spiders with Geolycosa-like pedipalps 


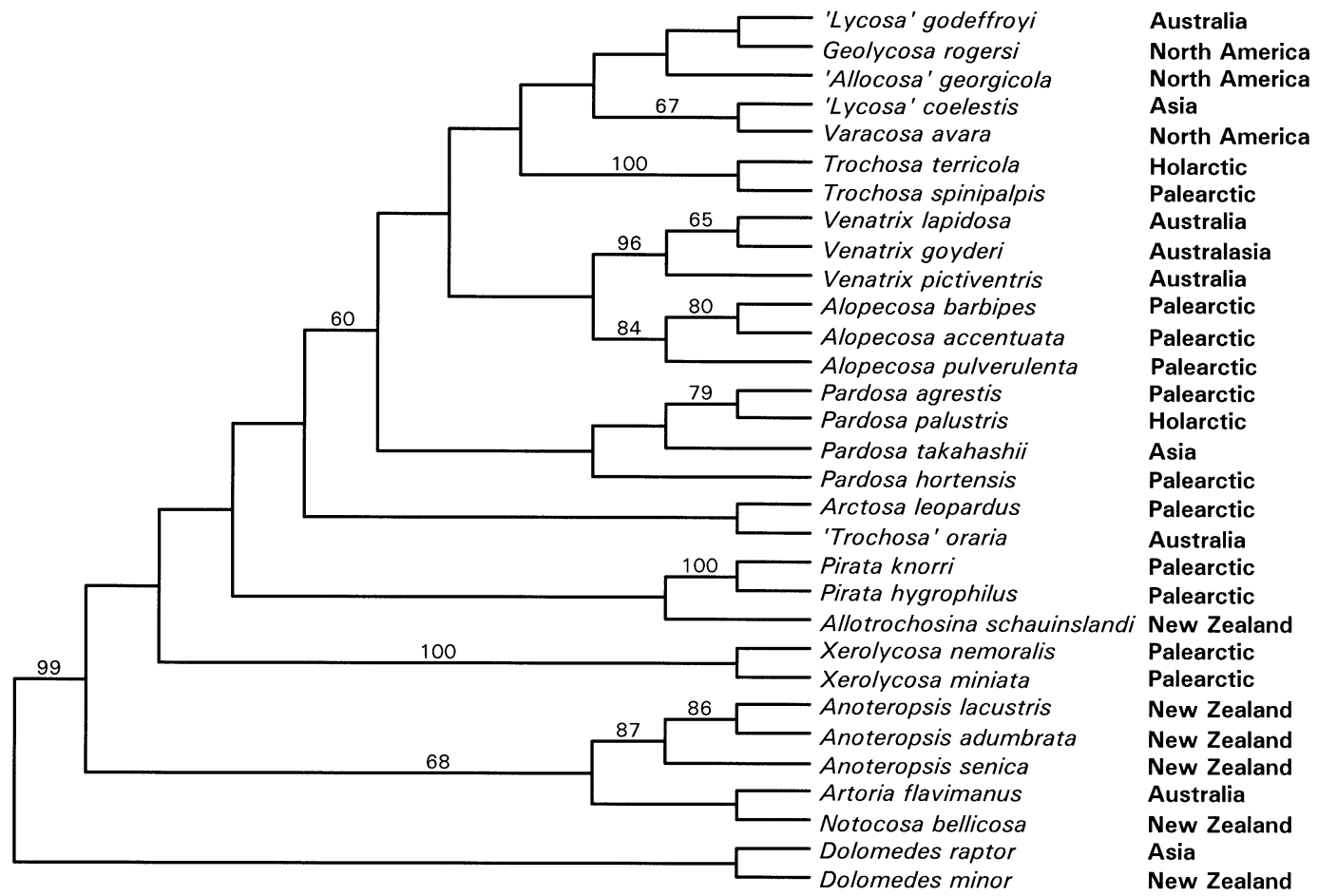

Figure 2.- One of two most parsimonious trees. The other tree differed by switching the positions of Lycosa godeffroyi and Allocosa georgicola. Bootstrap values above $50 \%$ are indicated above branches. Species distributions based on Platnick (2001) are shown on the right. Species that do not fit current generic definitions have the generic name in inverted commas.

(L. godeffroyi, G. rogersi, A. georgicola, $L$. coelestis and $V$. avara) but there is low $(<$ $50 \%$ ) bootstrap support for this clade. The Mediterranean genus Lycosa (sensu Zyuzin \& Logunov 2000) is unlikely to be appropriate for L. godeffroyi but this cannot be inferred from our analyses because we did not sequence any Mediterranean Lycosa species. However, both analyses have $L$. godeffroyi coming out with Geolycosa rogersi, which is a true Geolycosa. The strongly supported, monophyletic clade of three Venatrix exemplars supports the monophyly of Venatrix. In both analyses (Figs. 2, 3) Venatrix was sister to Alopecosa and it has been noted that they share a similar pedipalpal structure (Framenau \& Vink 2001). The clade containing the three Anoteropsis exemplars is monophyletic, which concurs with Vink (2002). Anoteropsis and Notocosa appear to be restricted to New Zealand (Vink 2002) and Artoria are most diverse in Australia but are also found in New Zealand, Papua New Guinea and the Philippines (Framenau 2002; Vink 2002). The monophyly of the clade containing exemplars from Anoteropsis, Artoria and Notocosa is supported in both analyses and all five species share a similar pedipalp configuration (Figs. 4-8) that includes a partially divided tegulum and similarities in the position and shape of the median apophysis (Vink 2002). The relationship of Notocosa bellicosa (Goyen 1887) to the other four species in the clade differs between the analyses. The parsimony analysis puts $N$. bellicosa as sister to Artoria flavimanus Simon 1909, whereas the bootstrap support $(61 \%)$ within the parsimony trees and maximum likelihood analysis have $N$. bellicosa as sister to a clade containing the other four species. This clade does not fit current subfamily definitions and, once the genera are revised, may be placed in its own subfamily.

When Trochosa oraria is not included in Trochosa, the subfamilies Pardosinae Simon 1898 and Lycosinae Simon 1898 as defined by Dondale (1986) are supported, except for Arctosa C.L. Koch 1847, which falls outside the Lycosinae in this analysis. Dondale (1986) 


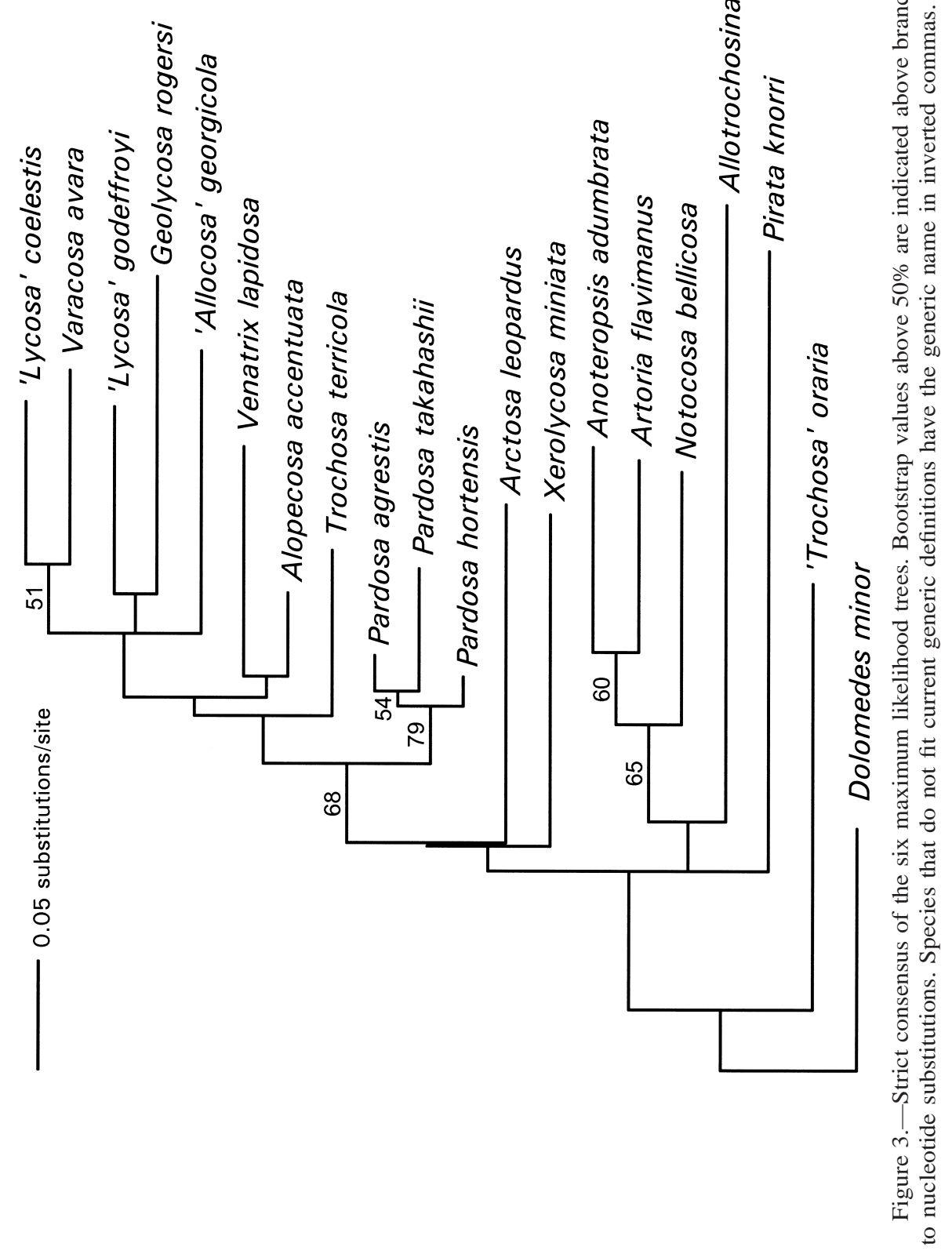



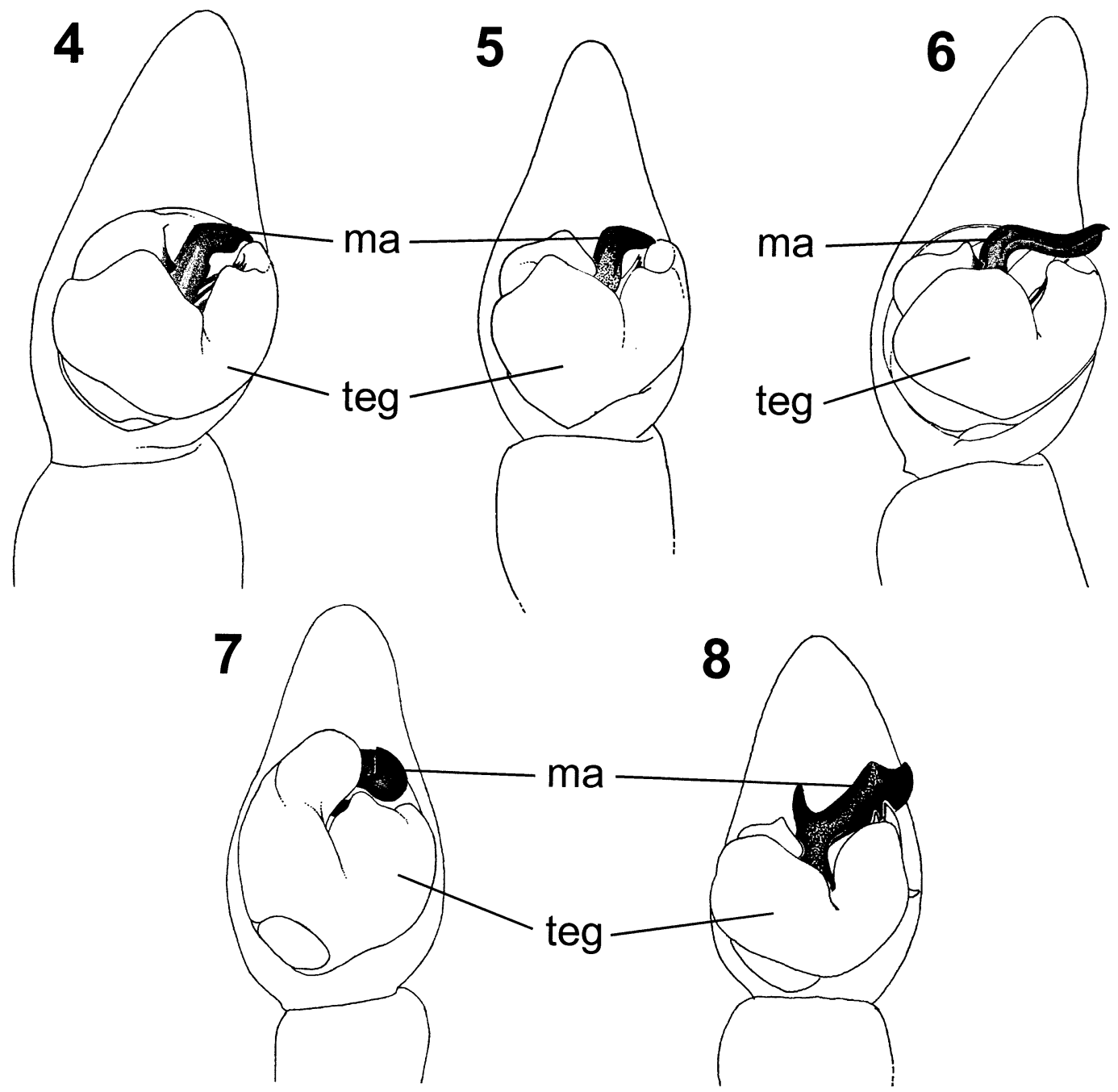

Figures 4-8.-Palps of (4) Anoteropsis adumbrata, (5) Anoteropsis lacustris, (6) Anoteropsis senica, (7) Notocosa bellicosa and (8) Artoria flavimanus showing partially divided tegulum (teg) and similarities in position and shape of median apophysis (ma).

suggested that the Lycosinae be divided into the "Trochosa group" and the "Lycosa group" but they are paraphyletic in our analyses. The placement of Allotrochosina in the subfamily Venoniinae (which also includes Pirata Sundevall 1833) by Vink (2001) is supported by the parsimony tree (Fig. 2) but not by the maximum likelihood tree (Fig. 3). It is worth noting that there is little bootstrap support for the lower branches of either tree. Further sequencing of several other genera may resolve these subfamily relationships.

While the pattern of distribution fits with a Gondwanan scenario a more detailed study of genetic divergence may reveal a better approximation of the time the faunas have been separated. Preliminary analyses presented here (Figs. 2,3) imply that Australasia had an ancestral fauna and was subsequently invaded by lycosine species, possibly via Asia through northern Australia. When New Zealand split away from Australia about 80 million years ago (Stevens et al. 1988), it is likely it retained an ancestral lycosid fauna. Only two lycosine species (Venatrix goyderi (Hickman 1944) and Geolycosa tongatabuensis (Strand 1911)) are found in New Zealand and it is likely that they have subsequently ballooned across to 
New Zealand; both species are widely distributed across Australia and the South Pacific respectively but, in New Zealand, they are limited to the warmer north of the North Island.

The phylogenies presented here are somewhat preliminary, as some genera found in Australia are not represented (e.g. Anomalosa Roewer 1960, Venonia Thorell 1894, Zoica Simon 1898). Further resolution of subfamily relationships could also be facilitated by the inclusion of exemplars from Allocosinae Dondale 1986, Sosippinae Dondale 1986, Tricassinae Alderweireldt \& Jocqué 1993, and Wadicosinae Zyuzin, 1985. The inclusion of at least one exemplar from Lycosa (sensu Zyuzin \& Logunov 2000) may help to confirm the relationship of that genus to other lycosine genera.

Results presented here suggest that $12 \mathrm{~S}$ DNA sequence data are useful for inferring phylogenies of closely related genera. However, these data appear to be too conservative for adequate resolution at the species level (Vink \& Mitchell 2002) and too fast for deeper relationships, inferred from bootstrap support of less than $50 \%$ shown for the lower branches of the parsimony tree (Fig. 2). Deeper relationships in the Lycosidae may be better resolved by the use of an even more slowly evolving gene region, such as 28S rDNA, which has been used to infer spider phylogeny at the family level (Hausdorf 1999).

In summary, we conclude that many current generic placements of Australasian species are incorrect; the New Zealand fauna is related to a subset of the Australian fauna and parts of the Australian fauna are related to the Asian/ Holarctic fauna, suggesting a subsequent invasion. Current subfamilies were found to be largely monophyletic but further work is required to fully resolve subfamily relationships.

\section{ACKNOWLEDGMENTS}

We thank the following people for help with the collection of fresh specimens: Marie Hudson, Jeff Cossum (Tasmanian Museum \& Art Gallery), Volker Framenau (University of Melbourne), Grace Hall (Landcare Research), Rowan Emberson (Lincoln University) and Philip Howe (South Canterbury Museum). Thanks to Gail Stratton (University of Mississippi) for collecting and sending fresh specimens from the US. We are indebted to Dianne
Gleeson (Landcare Research) and Martyn Kennedy (University of Glasgow) for assisting with maximum likelihood analyses. Volker Framenau, Phil Sirvid and Eric Scott provided helpful comments on the manuscript. This research was made possible by funding from Landcare Research, the Miss E.L. Hellaby Indigenous Grasslands Research Trust and the Soil, Plant and Ecological Sciences Division, Lincoln University.

\section{LITERATURE CITED}

Alderweireldt, M. 1991. A revision of the African representatives of the wolf spider genus Evippa Simon, 1882 (Araneae, Lycosidae) with notes on allied species and genera. Journal of Natural History 25:359-381.

Alderweireldt, M. 1999. A revision of Central African Trabea (Araneae, Lycosidae) with the description of two new species from Malawi and a redescription of $T$. purcelli. Journal of Arachnology 27:449-457.

Benson, D.A., I. Karsch-Mizrachi, D.J. Lipman, J. Ostell, B.A. Rapp \& D.L. Wheeler. 2000. GenBank. Nucleic Acids Research 28:15-18.

Brignoli, P.M. 1983. A Catalogue of the Araneae Described Between 1940 and 1981. Manchester University Press, Manchester.

Churchill, T.B. 1993. Effects of sampling method on composition of a Tasmanian coastal heathland spider assemblage. Memoirs of the Queensland Museum 33:475-481.

Croom, H.B., R.G. Gillespie \& S.R. Palumbi. 1991. Mitochondrial DNA sequences coding for a portion of the RNA of the small ribosomal subunits of Tetragnatha mandibulata and Tetragnatha hawaiensis (Araneae, Tetragnathidae). Journal of Arachnology 19:210-214.

Dippenaar-Schoeman, A.S. \& R. Jocqué. 1997. African Spiders: An Identification Manual. Plant Protection Research Institute, Pretoria.

Dondale, C.D. 1986. The subfamilies of wolf spiders (Araneae: Lycosidae). Actas X Congreso Internacional de Aracnología, Jaca, España 1:327332.

Dondale, C.D. \& J.H. Redner. 1978. Revision of the Nearctic wolf spider genus Schizocosa (Araneida: Lycosidae). Canadian Entomologist 110:143181.

Dondale, C.D. \& J.H. Redner. 1979. Revision of the wolf spider genus Alopecosa Simon in North America (Araneae: Lycosidae). Canadian Entomologist 111:1033-1055.

Dondale, C.D. \& J.H. Redner. 1983a. Revision of the wolf spiders of the genus Arctosa C.L. Koch in North and Central America (Araneae: Lycosidae). Journal of Arachnology 11:1-30.

Dondale, C.D. \& J.H. Redner. 1983b. The wolf spi- 
der genus Allocosa in North and Central America (Araneae: Lycosidae). Canadian Entomologist 115:933-964.

Dondale, C.D. \& J.H. Redner. 1990. The Wolf Spiders, Nurseryweb Spiders, and Lynx Spiders of Canada and Alaska. Araneae: Lycosidae, Pisauridae, and Oxyopidae. Agriculture Canada, Canada.

Fang, K., C.-C. Yang, B.-W. Lue, S.-H. Chen \& K.Y. Lue. 2000. Phylogenetic corroboration of superfamily Lycosoidae spiders (Araneae) as inferred from partial mitochondrial $12 \mathrm{~S}$ and $16 \mathrm{~S}$ ribosomal DNA sequences. Zoological Studies 39:107-113.

Felsenstein, J. 1985. Confidence limits on phylogenies: An approach using the bootstrap. Evolution 39:783-791.

Framenau, V.W. 2002. Review of the wolf spider genus Artoria Thorell (Araneae, Lycosidae). Invertebrate Systematics 16:in press.

Framenau, V.W., R. Manderbach \& M. Baehr. 2002. Riparian gravel banks of upland and lowland rivers in Victoria (south-east Australia): arthropod community structure and life history patterns along a longitudinal gradient. Australian Journal of Zoology 50:103-123.

Framenau, V.W. \& C.J. Vink. 2001. Revision of the wolf spider genus Venatrix Roewer (Araneae: Lycosidae). Invertebrate Taxonomy 15:927-970.

Forster, R.R. 1975. The spiders and harvestmen. Pp. 493-505. In Biogeography and Ecology in New Zealand (G. Kuschel, ed.). W. Junk, The Hague.

Gillespie, R.G., H.B. Croom \& S.R. Palumbi. 1994. Multiple origins of a spider radiation in Hawaii. Proceedings of the National Academy of Sciences of the United States of America 91:22902294.

Griswold, C.E. 1993. Investigations into the phylogeny of the lycosid spiders and their kin (Arachnida: Araneae: Lycosoidea). Smithsonian Contributions to Zoology 539:1-39.

Hausdorf, B. 1999. Molecular phylogeny of araneomorph spiders. Journal of Evolutionary Biology 12:980-985.

Heimer, S. \& W. Nentwig. 1991. Spinnen Mitteleuropas: Ein Bestimmungsbuch. Verlag Paul Parey, Berlin.

Hickson, R.E., C. Simon, A. Cooper, G.S. Spicer, J. Sullivan \& D. Penny. 1996. Conserved sequence motifs, alignment, and secondary structure for the third domain of animal 12S rRNA. Molecular Biology and Evolution 13:150-169.

Hodge, S. \& C.J. Vink. 2000. An evaluation of Lycosa hilaris as a bioindicator of organophosphate insecticide contamination. New Zealand Plant Protection 53:226-229.

Humphreys, W.F. 1976. The population dynamics of an Australian wolf spider, Geolycosa godeffroyi
(L. Koch 1865) (Araneae: Lycosidae). Journal of Animal Ecology 45:59-80.

Kambhampati, S. \& P.T. Smith. 1995. PCR primers for the amplification of four insect mitochondrial gene fragments. Insect Molecular Biology 4: 233-236.

Koch, L. 1877. Die Arachniden Australiens. Bauer and Raspe, Nürnberg.

McKay, R.J. 1975. The wolf spiders of Australia (Araneae: Lycosidae): 5. Two new species of the bicolor group. Memoirs of the Queensland $\mathrm{Mu}-$ seum 17:313-318.

McKay, R.J. 1979. The wolf spiders of Australia (Araneae: Lycosidae): 13. The genus Trochosa. Memoirs of the Queensland Museum 19:277298.

Platnick, N.I. 2001. The World Spider Catalog. http: //research.amnh.org/entomology/spiders/cata$\log 81-87$. The American Museum of Natural History.

Posada, D. \& K.A. Crandall. 1998. Modeltest: testing the model of DNA substitution. Bioinformatics 14:817-818.

Roewer, C.F. 1951. Neue Namen einiger AraneenArten. Abhandlungen des Naturwissenschaftlichen Vereines zu Bremen 32:437-456.

Roewer, C.F. 1955 (imprint date 1954). Katalog der Araneae von 1758 bis 1940. Institut Royal de Sciences Naturelles de Belgique, Bruxelles.

Roewer, C.F. 1959 (imprint date 1958). Araneae Lycosaeformia II (Lycosidae). Exploration du Parc National de 1'Upemba 55:1-518.

Roewer, C.F. 1960 (imprint date 1959). Araneae Lycosaeformia II (Lycosidae) (Fortsetzung und Schluss). Exploration du Parc National de l'Upemba 55:519-1040.

Russell-Smith, A. 1982. A revision of the genus Trabaea Simon (Araneae: Lycosidae). Zoological Journal of the Linnean Society 74:69-91.

Simon, C., S. Pääbo, T.D. Kocher \& A.C. Wilson. 1990. Evolution of the mitochondrial ribosomal RNA in insects as shown by the polymerase chain reaction. Pp. 235-244. In Molecular Evolution, U.C.L.A. Symposia on Molecular and Cellular Biology, New Series, Vol. 122 (M. Clegg \& S. O’Brien, eds.). Liss, New York.

Simon, C., F. Frati, A. Beckenbach, B. Crespi, H. Liu \& P. Flook. 1994. Evolution, weighting, and phylogenetic utility of mitochondrial gene sequences and a compilation of conserved polymerase chain reaction primers. Annals of the Entomological Society of America 87:651-701.

Sivasubramaniam, W., S.D. Wratten \& J. Klimaszewski. 1997. Species composition, abundance, and activity of predatory arthropods in carrot fields, Canterbury, New Zealand. New Zealand Journal of Zoology 24:205-212.

Stevens, G.R., M. McGlone \& B. McCulloch. 1988. 
Prehistoric New Zealand. Heinemann Reed, Auckland.

Swofford, D.L. 2000. PAUP*: Phylogenetic analysis using parsimony (and other methods), version 4.0b4a. Sinauer Associates, Sunderland, Massachusetts.

Thompson, J.D., D.G. Higgins \& T.J. Gibson. 1994. CLUSTAL W: improving the sensitivity of progressive multiple sequence alignment through sequence weighting, positions-specific gap penalties and weight matrix choice. Nucleic Acids Research 22:4673-4680.

Vink, C.J. 2001. A revision of the genus Allotrochosina Roewer (Lycosidae: Araneae). Invertebrate Taxonomy 15:461-466.

Vink, C.J. 2002. Lycosidae (Arachnida: Araneae). Fauna of New Zealand, in press.

Vink, C.J. \& A.D. Mitchell. 2002. 12S DNA sequence data confirms the separation of Alopecosa barbipes and Alopecosa accentuata (Araneae: Lycosidae). Bulletin of the British Arachnological Society 12:in press.

White, T.J., T. Bruns, S. Lee \& J. Taylor. 1990. Amplification and direct sequencing of fungal ribosomal RNA genes for phylogenetics. Pp. 315-
322. In PCR Protocols: A Guide to Methods and Applications (M. A. Innis, D. H. Gelfand, J. J. Sninsky \& T. J. White, eds.). Academic Press, San Diego.

Yang, Z. 1994. Maximum likelihood phylogenetic estimation from DNA sequences with variable rates over sites: Approximate methods. Journal of Molecular Evolution 39:306-314.

Zehethofer, K. \& C. Sturmbauer. 1998. Phylogenetic relationships of Central European wolf spiders (Araneae: Lycosidae) inferred from 12S ribosomal DNA sequences. Molecular Phylogenetics and Evolution 10:391-398.

Zyuzin, A.A. 1993. Studies on the wolf spiders (Araneae: Lycosidae). I. A new genus and species from Kazakhstan, with comments on the Lycosidae. Memoirs of the Queensland Museum 33: 693-700.

Zyuzin, A.A. \& D.V. Logunov. 2000. New and little-known species of the Lycosidae from Azerbaijan, the Caucasus (Araneae, Lycosidae). Bulletin of the British Arachnological Society 11: 305-319.

Manuscript received 1 July 2001, revised 4 February 2002. 